\title{
Emerging trends in management of propionic acidemia
}

\author{
Tendências emergentes no manejo da academia propiônica
}

Muhammad Rafique'

\begin{abstract}
Objetivo: To evaluate the therapeutic agents used during metabolic crises and in long-term management of patients with propionic acidemia (PA). Materials and methods: The records of PA patients were retrospectively evaluated. Results: The study group consisted of 30 patients with 141 admissions. During metabolic crises, hyperammonemia was found in 130 (92\%) admissions and almost all patients were managed with normal saline, $\geq 10 \%$ dextrose, and restriction of protein intake. In 56 (40\%) admissions, management was done in intensive care unit, 31 (22\%) with mechanical ventilation, $10(7 \%)$ with haemodialysis, $16(11 \%)$ with vasopressor agents, and $12(9 \%)$ with insulin. In the rescue procedure, L-carnitine was used in $135(96 \%)$ patients, sodium bicarbonate in $116(82 \%)$, sodium benzoate in $76(54 \%)$, and metronidazole in $10(7 \%)$, biotin in about one-quarter, L-arginine in one third, and antibiotics in three-quarter of the admissions. Blood/packed RBCs were used in $28(20 \%)$ patients, platelets in $26(18 \%)$, fresh frozen plasma in $8(6 \%)$, and granulocyte-colony stimulating factors in $10(7 \%)$ admissions. All patients were managed completely/partially with medical nutrition formula plus amino acid mixture, vitamins and minerals. For long-term management $24(80 \%)$ patients were on L-carnitine, 22 (73\%) on sodium benzoate, $6(20 \%)$ on biotin, one half on alkaline therapy and $4(13 \%)$ on regular metronidazole use. Almost all patients were on medical formula and regular follow-up. Conclusion: Aggressive and adequate management of acute metabolic crises with restriction of protein intake, stabilization of patient, reversal of catabolism, and removal of toxic metabolites are essential steps. Concerted efforts to ensure adequate nutrition, to minimize the risk of acute decompensation and additional therapeutic advances are imperative to improve the outcome of PA patients. Arq Bras Endocrinol Metab. 2014;58(3):237-42
\end{abstract}

\section{Keywords}

Propionate; therapeutic agents; management; latest trends; metabolic crises; hyperammonaemia

\section{RESUMO}

Objetivo: Avaliar os agentes terapêuticos usados durante as crises metabólicas e para o manejo de longo prazo de pacientes com academia propiônica (AP). Materiais e métodos: Avaliação retrospectiva das fichas médicas de pacientes com AP. Resultados: 0 grupo estudado consistiu de 30 pacientes com 141 hospitalizações. Durante as crises metabólicas, a hiperamonemia foi observada em 130 (92\%) pacientes hospitalizados e quase todos foram tratados com solução salina regular, $\geq 10 \%$ dextrose e restrição da ingestão de proteína. Em $56(40 \%)$ das hospitalizações, o manejo foi feito na unidade de terapia intensiva, 31(22\%) com ventilação mecânica, 10 (7\%) com hemodiálise, $16(11 \%)$ com vasopressores e 12 (9\%) com insulina. Para o resgate, a L-carnitina foi usada em 135 (96\%) pacientes, o bicarbonato de sódio em $116(82 \%)$, o benzoato de sódio em 76 (54\%), o metronidazole em $10(7 \%)$, a biotina em cerca de um quarto, a L-arginina em um quarto e antibióticos em três quartos dos pacientes hospitalizados. Sangue/concentrado de hemácias foram usados em $28(20 \%)$, plaquetas em 26 (18\%), plasma fresco congelado em $8(6 \%)$ e fatores estimulantes de colônias de granulócitos em 10 (7\%) pacientes hospitalizados. Todos os pacientes foram manejados completamente/parcialmente com fórmula de nutrição hospitalar mais uma mistura de aminoácidos, vitaminas e minerais. Para o manejo de longo prazo, $24(80 \%)$ dos pacientes foram tratados com L-carnitina, $22(73 \%)$ com benzoato de sódio, $6(20 \%)$ com biotina, a metade com tratamento alcalino e $4(13 \%)$ com uso regular de metronidazole. Quase todos os pacientes foram tratados com fórmulas médicas e acompanhamento regular. Conclusão: 0 manejo adequado e agressivo de crises metabólicas com restrição da ingestão de proteína, estabilização do pacientes e reversão do catabolismo, e remoção dos metabólitos tóxicos são passos essenciais. Esforços concentrados para garantir a nutrição adequada, minimizar o risco de descompensação aguda e avanços terapêuticos adicionais são imperativos na melhora dos desfechos de pacientes com AP. Arq Bras Endocrinol Metab. 2014;58(3):237-42

\section{Descritores}

Propionato; agentes terapêuticos; manejo; últimas tendências; crises metabólicas; hiperamonemia
${ }^{1}$ Central Aseer Hospital Abha, Kingdom of Saudi Arabia

Correspondence to: Muhammad Rafique Associate Professor, Department of Paediatrics, Fatima Jinnah Medical College, University of Health Sciences Lahore, Pakistan mrafiquelhr@hotmail.com

Received on May/23/2013 Accepted on Jan/24/2014 


\section{INTRODUCTION}

$\mathrm{P}$ ropionic acidemia (PA) is a rare metabolic disorder, caused by deficiency of a mitochondrial enzyme propionyl CoA carboxylase (PCC) resulting in accumulation of highly toxic metabolites. The disorder is unusually frequent in Saudi Arabia, and has been reported to occur in 1 in 2,000 to 1 in 5,000 live births in this region ( 1 ). About 80\% PA patients are early-onset cases (diagnosed $<3$ months of age). They have more severe disease and classically present, in the neonatal period, lethargy, vomiting, refusal to feed, hypotonia and, less frequently, dehydration and seizures. Some patients have late-onset disease (manifested any time after three months of age), show milder symptoms, and long survival rate. PA is usually associated with long-term neurological complications and is characterized by recurrent episodes of metabolic crises (2). Several metabolites and physiological stressors are thought to account for many of the acute and chronic disease manifestations. Common findings include metabolic acidosis, ketosis, hyperammonemia, increased incidence of infections and bone marrow suppression. During metabolic crises, total protein restriction, reversal of catabolism and rapid detoxification are essential life-saving steps to prevent acute brain injury, severe morbidity and mortality (2). Treatment options include low protein diet, carnitine, biotin, a precursor free amino acid formula and alkaline therapy. Hemodiafilteration/hemodialysis is recommended for severe hyperammonemia, extreme acidosis, and dangerous electrolyte imbalance (3). Packed red blood cells (RBCs) transfusion and/or granulocyte colony stimulating factors (G-CSF) are recommended in anemia, neutropenia, or bone marrow suppression (2). Antibiotics are commonly used during metabolic crises, which have strong association with immuno-suppression and sepsis (1).

The objective of this study was to evaluate the therapeutic agents used for acute management during metabolic crisis and those used on a regular basis for long term management of the PA patients to minimize the risk of recurrent metabolic decompensation.

\section{MATERIALS AND METHODS}

This retrospective study was conducted in a tertiary care public hospital from January 2001 to March 2013. Our study group included 30 children, in a total of 141 admissions. The records of all patients who were admitted in the Department of Pediatrics with confirmed diagno- sis of PA during the study period were evaluated. The patients were diagnosed based on high propionylcarnitine level in blood, detected by Tandem Mass Spectrometry; high level of propionate excreted in the urine; enzyme analysis; and genetic studies. All cases were reviewed for the following variables - age of the patients at diagnosis, age at last admission before this study, family history of PA, therapeutic agents/blood products used, and procedures carried out to manage acute problems/ imbalances developed during metabolic crises. Prophylactic agents regularly used for long-term management to avoid metabolic decompensations were also recorded. Information was gathered regarding admissions in neonatal intensive care unit (NICU), pediatric intensive care unit (PICU), mechanical ventilation during metabolic decompensation. The percentage of patients discharged after recovery and who died during metabolic crises was also calculated. Weight and height/length of the patients were recorded. These anthropometric parameters were plotted on growth charts specific for Saudi children and their normal-for-age percentages were calculated. Percentages of under-nutrition/wasting (weight $<$ normal for age) and short stature/stunting (height < normal for age) of the PA patients were calculated. The data were analysed using Microsoft Excel spread sheets. The results were expressed in percentages. The study was approved by the Research and Ethical Committee of the institution (Record \# 2012 - 10 - 08).

\section{RESULTS}

We studied thirty patients and their 141 admissions were analysed. Table 1 demonstrates demographic characteristics of patients with PA. Twenty eight (93\%) patients were early presenters (diagnosed within three months of age) and two (7\%) children manifested their disease after three months of age (late-onset cases). Our 24 $(80 \%)$ patients were undernourished/wasted (weight $<90 \%$ expected for age) and $19(63 \%)$ were stunted/ short stature (length/height $<95 \%$ expected for age) (4). Table 2 shows detail of therapeutic agents and blood products used during acute metabolic crises and prophylactic agents used regularly for long-term management to avoid metabolic decompensations. During metabolic crises, medical nutrition therapy (MNT), intravenous (IV) dextrose and normal saline were used for all patients to correct dehydration and to reverse catabolism. In $12(8.5 \%)$ admissions of PA patients, insulin was also added to drive glucose into the cells to rapidly achieve 
Table 1. Data of patients with PA. Values are given in $n(\%) /$ mean [SD]

\begin{tabular}{lc}
\hline Variable of patients & $\mathbf{N}=\mathbf{3 0}(\%) /$ mean[SD] \\
\hline Male & $18(60)$ \\
Consanguinity of parents & $18(60)$ \\
History of PA in siblings & $10(33.3)$ \\
NICU admission at time of diagnosis & $21(70)$ \\
Mean age at diagnosis (yr) & $0.12[0.26]$ \\
$<3$ months (early onset cases) & $28(93.3)$ \\
After 3 months (late onset cases) & $2(6.7)$ \\
Present age (yr) (range: 3 day-14 yr) & $2.59[4.45]$ \\
No of admissions/patient & $4.90[6.19]$ \\
Frequency of admissions/yr & $4.60[2.40]$ \\
Mean \% of weight expected for age & $73.53[16.6]$ \\
Mean \% of height expected for age & $91.3[8.29]$ \\
Patients were & \\
On nasogastric/gastric tube feeding & $6(20)$ \\
On home oxygen therapy & $2(6.7)$ \\
Look after in social home & $2(6.7)$ \\
Cerebral palsy & $4(13.3)$ \\
Seizures/epilepsy & $12(40)$ \\
Discharged after recovery & $28(93.3)$ \\
Died due to septic shock and MOF & $2(6.7)$ \\
\hline
\end{tabular}

NICU: neonatal intensive care unit; MOF: multi-organ failure.

anabolism. Mean hospital stay of the patients was 9.32 \pm 8.15 days. In $56(39.71 \%)$ admissions, patients were admitted in the PICU, with mean duration of stay 8.9 \pm 8.47 days. In $31(22 \%)$ admissions, patients were mechanically ventilated with mean duration of $7.9 \pm 6.97$ days. In 10 (7.1\%) admissions of our patients, hemodialysis was performed for quick recovery of metabolic crisis.

\section{DISCUSSION}

\section{Stabilization, if critical}

In stressful conditions, acute metabolic crises with hyperammonemia are common in PA individuals. For their management, patients should be stabilized with IV fluid, glucose, restriction of proteins, vasopressors (if hypotension persists), and mechanical ventilation (if oxygen saturation is not maintained by alternative measures) (3). In this study, almost all the patients were managed with parenteral normal saline, $\geq 10 \%$ dextrose ( 1.5 times maintenance requirement of IV fluids), and restriction of protein intake. In $22 \%$ admissions, patients were mechanically ventilated, and in $11 \%$ admissions, inotropic agents were used to maintain blood pressure.
Table 2. Therapeutic agents used during metabolic crises and for longterm management in $n=141$ admissions of 30 patients with PA

\begin{tabular}{lc}
\hline Therapeutics agents & $\mathbf{n ~ ( \% )}$ \\
\hline During metabolic crises & \\
L-carnitine & $135(95.7)$ \\
Biotin & $32(22.7)$ \\
L-arginine & $50(35.5)$ \\
Sodium bicarbonate & $116(82.3)$ \\
Sodium benzoate & $76(53.9)$ \\
Metronidazole & $10(7.1)$ \\
Laxatives & $6(4.3)$ \\
Blood/packed red blood cells transfusion & $28(19.9)$ \\
Platelets & $26(18.4)$ \\
Granulocyte-colony stimulating factors & $10(7.1)$ \\
Fresh frozen plasma & $8(5.7)$ \\
Intravenous immunoglobulin & $2(1.4)$ \\
Antibiotics & $105(74.4)$ \\
Antifungal/antiviral (acyclovir) & $9(6.4)$ \\
Vesopressor & $16(11.3)$ \\
Anticonvulsants & $18(12.8)$ \\
Insulin infusion & $12(8.5)$ \\
Regular use for prophylaxis in $n=30$ pts. & \\
Special medical food & $30(100)$ \\
L-carnitine & $24(80)$ \\
Sodium benzoate & $22(73.3)$ \\
Sodium bicarbonate & $15(50)$ \\
Biotin & $6(20)$ \\
Metronidazole & $4(13.3)$ \\
\hline & \\
\hline
\end{tabular}

\section{Reversal of catabolism}

- Acute episode of hyperammonemia is always an emergency and a life-threatening episode (5). We found hyperammonemia in $95 \%$ admissions. Its treatment consists of hydration, correction of acidosis with IV glucose, insulin, carnitine, sodium benzoate, and vitamin therapy associated with a hypercaloric, protein-free diet (6). During metabolic decompensation, stop all sources of protein (enteral and parenteral) to cut exogenous propionate production, and to inhibit catabolism of endogenous proteins. Give non-protein calory in the form of parenteral dextrose $\geq 10 \%$ with necessary electrolytes. Intralipids can be added to provide more calories, if needed. To drive glucose into the cells and reverse catabolism, insulin infusion can be added (3). In the current study, almost all pa- 
tients were managed along the same lines. Insulin infusion was used in $9 \%$ admissions. In a few patients, intralipids were also added. Hemodialysis is recommended in cases of ammonia levels $>300 \mathrm{umol} / \mathrm{L}$, extreme acidosis/electrolyte imbalance, coma, deterioration, and failure to improve. In $7 \%$ admissions, hemodialysis was performed, whereas Grunert and cols. reported this figure as $15 \%$ (7). In $40 \%$ admissions, our patients were managed in the PICU, which is compatible with another case series (7).

- L-carnitine conjugates with propionate and promotes transfer out of the mitochondria, so it can be excreted in the urine. It is helpful to eliminate the use of sodium bicarbonate for metabolic correction, and to correct its deficiency, which is a common finding in PA (7). Broadly in line with another report (equal to 93\%) (7), L-carnitine was used in $96 \%$ admissions of our patients, while other authors reported it as equal to $82 \%(2)$.

- In the acute phase of a not yet diagnosed metabolic patient with hyperammonemia, it is useful to start a nitrogen scavenger, sodium benzoate (3). In a case series, alternative pathway medications included sodium benzoate in $80 \%$ patients, sodium phenyl acetate in $40 \%$, metronidazole in $40 \%$, and sodium bicarbonate in $20 \%$ (8). In children with inborn error of metabolism with continued production of acid (despite normal tissue perfusion and oxygenation); sodium bicarbonate is usually an essential part of treatment of metabolic acidosis (9). In the present study, sodium bicarbonate was used in $82 \%$ admissions, sodium benzoate in $54 \%$, and metronidazole in 7\%. A big portion of propionate $(20-30 \%)$ is produced as food is metabolised by bacteria in the gut, which can be alleviated by using non-absorbable oral antibiotics, such as metronidazole/neomycin, which have been reported to be helpful in improving metabolic crises. Laxative agents, such as lactulose, increase gut motility and acidify the intestine, thus decreasing ammonia uptake $(3,5,11)$. During decompensation, we used metronidazole in $7 \%$ admissions, and laxatives in $4 \%$. However, a report of metronidazole use in PA patients was as high as $47 \%$ (8), and another one was as $40 \%$ (metronidazole alone in $20 \%$ patients, and metronidazole plus colistin in another $20 \%$ ) (7).
- N-carbamylglucomate has been shown to be beneficial in decreasing ammonia levels in acute hyperammonemia in patients with $\mathrm{PA}$ $(6,10,11)$.

- PCC is a biotin-dependent enzyme responsible for propionate metabolism in mitochondria. Biotin has been used by some researchers during metabolic crises $(6,8)$. This data is in agreement with our study, in which biotin was used in about one quarter of the admissions of PA patients.

- In some case series, L-arginine has also been used in acute management of hyperammonemia $(5,12)$. Consistently, we also used it in about one third of the admissions.

- Antimicrobial therapy is recommended during metabolic decompensation as PA is associated with suppression of the immune system and increased risk of infections (10). In line with $\mathrm{Al}$ Essa and cols. (1) antibiotics were used in three quarter of the admissions of our patients. Similarly, in some patients of this study, antifungal and antiviral therapy was also used.

- Proteins should be re-introduced within 24-36 hours of initiation of therapy during metabolic crisis. Consistently, within 24-48 hours, we also re-started proteins in our patients in the form of MNT (7).

- Packed RBCs and other blood product transfusions are recommended if patients are anemic, immunocompromised or have bone marrow suppression $(3,12)$. In this study, blood/Packed RBCs were transfused in $20 \%$ admissions, platelets in 18\%, and fresh frozen plasma in 6\%. GCSF was used in $7 \%$ admissions to counteract neutropenia caused by bone marrow suppression, which is consistent with another report (13).

- In agreement with Land and Roberts' report, immunoglobulins were used in some of our patients to enhance their immunity (13).

\section{Transition from acute to chronic management}

- For long-term management of PA patients, nutritional support regimen is performed with MNT. It has been described that, with advancing age, tolerance to natural proteins increases, and metabolic decompensation occur less frequently. In a case series, most of the patients 
received a diet that restricted natural protein. In addition, a nonpropiogenic amino acid mixture was supplemented to meet age-appropriate protein intake recommendations $(7,14,15)$. In the present study, almost all patients were found to be managed completely/partially with MNT, amino acid mixture, vitamins, and minerals.

- Many PA patients were poor oral feeders. Nasogastric/gastrostomy $(\mathrm{NG} / \mathrm{G})$ tube feeding can be used to meet daily metabolic nutrition therapy goals when patients are anorexic, as it is often seen in PA $(3,15)$. Our $20 \%$ children were exclusively on NG/G tube feeding. However, Grunert and cols. reported this figure as $15 \%(7)$.

- Regular use of carnitine is required to avoid metabolic decompensations and to prevent secondary deficiency of this agent $(7,15)$. In accordance with another report (7), 92\% of our patients used it regularly.

- Some patients need alkaline therapy for longterm management (9). This is consistent with our study. One half of our patients were on regular sodium bicarbonate therapy.

- In addition to prevention of constipation, for gut flora control, long-term oral antimicrobial (metronidazole) therapy may offer significant clinical benefits in children with PA $(7,15)$. In line with another report, 13\% of our patients were on long-term metronidazole therapy (7).

- Screening studies, such as electrocardiogram, echocardiogram, hearing screening, and optic field assessment are regularly recommended in PA patients $(3,15)$. Most of our patients were on regular follow-up, at the current/another centre.

- Physical and occupational therapy should start as soon as possible in patients with physical disabilities (3). This is compatible with our management of PA patients.

- Similar to our policy, parental education about the disease and management has also been considered to be crucial $(3,12)$.

- Some researchers have described the role of growth hormone to improve lean body mass and linear growth and to increase tolerance to natural proteins in PA patients (15).

Long-term management of the individuals with PA is imperative. The severity of radiological abnormalities seems to correlate with the degree of compliance to therapy, but not with the number of hospital or PICU admissions (16). Liver transplantation may be considered in individuals with recurrent episodes of hyperammonemia/metabolic decompensation that are not adequately controlled with medical therapy $(9,15)$. Last, development in the field of somatic gene therapy are also very promising (8).

There were some limitations in this study due to unavailability of complete records of some patients, especially those who were being followed up at other centres.

\section{CONCLUSION}

Aggressive identification of PA patients and initiation of therapy are necessary to prevent severe morbidity and mortality. During metabolic decompensation, reversal of catabolism and removal of toxic compounds is a life-saving measure. Concerted efforts are needed to ensure adequate nutrition of PA patients, to minimize the risk of acute decompensation, and to treat episodes of metabolic crises promptly. The long-term, firm education and guidance of parents and patients by established diagnostic and therapeutic centers, and additional therapeutic advances are indispensible for a beneficial outcome.

Grant/support: no financial support was provided by any organization for this study

Disclosure: no potential conflict of interest relevant to this article was reported.

\section{REFERENCES}

1. Al Essa M, Rahbeeni Z, Jumaah S, Joshi S, Al Jishi E, Rashed MS, et al. Infectious complications of propionic acidemia in Saudi Arabia. Clin Genet. 1998;54:90-5.

2. van der Meer SB, Poggi F, Spada M, Bonnefont JP, Ogier H, Hubert $P$, et al. Clinical outcome and long term management of 17 patients with propionic acidemia. Eur J Pediatr. 1996;155:205-10.

3. Chapman KA, Gropman A, MacLeod E, Stagni K, Summar ML, Ueda K, et al. Acute management of propionic acidemia. Mol Genet Metab. 2012;105(1):16-25.

4. Keane V. Assessment of growth. In: Kleigman RM, Behrman RE, Jenson HB, Stanton BF.18th ed. Philadelphia PA: W.B. Saunders; 2007. p. 70-4.

5. Haberle J.The management of hyperammonaemia. Eur J Pediatr. 2011;170:21-34.

6. Daniotti M, la Marca G, Fliorini P, Filippi L. New development in the treatment of hyperammonemia: emerging use of carglumic acid. Int J Gen Med. 2011;4:21-8. 
7. Grunert SC, Mullerleile S, De Silva L, Barth M, Walter M, Walter $\mathrm{K}$, et al. Propionic acidemia: clinical course and outcome in 55 pediatric and adolescent patients. Orphanet $\mathrm{J}$ Rare Dis. 2013;8:6-14.

8. Vara R, Turner C, Mundy H, Heaton ND, Rela M, Mieli-Vergani G, et al. Liver transplantation for propionic acidemia in children. LiverTranspl. 2011;17:661-7.

9. Jones SA, Walter JH. Diagnosis and treatment of severe metabolic acidosis. Paediatr Child Health. 2007;17(7):260-5.

10. Gosen LV. Organic acidemias: a methylmalonic and propionic acidemia. J Pediatr Nurs. 2008;23(3):225-33.

11. Tuchman M, Caldovic L, Daikhin Y, Horyn O, Nissim I, Nissim I, et al. $\mathrm{N}$-carbamylglutamate markedly enhances ureagenesis in $\mathrm{N}$-acetylglutamate deficiency and propionic acidemia as measured by isotopic incorporation and blood biomarkers. Pediatr Res. 2008;64(2):213-7.
12. Lehnert W, Sperl W, SuormalaT, Baumgartner ER, et al. Propionic acidemia: clinical, biochemical and therapeutic aspects. Eur J Pediatr. 1994;153(7 Suppl 1):S68-80.

13. Land MH, Roberts RL. Neutropenia and hypo-gammaglobulinemia in propionic acidemia. J Allergy Clin Immunol. 2006(Suppl 1);117(2):S172.

14. Ogier de Boulny H, Dionisi-Vici C, Wendel U. Branched-chain organic acidurias/acidemias. In: Saudubray JM, van den Berghe G, Walter JH (eds). Inborn metabolic diseases. Diagnosis and treatment, 5th edn. Springer, Heidelberg; 2012. p. 277-96.

15. Sutton VR, Chapman KA, Gropman AL, MacLeod E, Stagni K, Summar ML, et al. Chronic management and health supervision of individuals with propionic acidemia. Mol Genet Metab. 2012;105:26-33.

16. Brismar J, Ozand PT. CT and MRI of the brain in disorders of the propionate and methylmelonate metabolism AJNR Am J Neuroradiol. 1994;15:1459-73. 